\title{
The Political Process of Bureaucratic Reform: Wonosobo Regional Government Experience from 2011-2015
}

\author{
I Made Krisnajaya ${ }^{1}$, Suripto ${ }^{2}$, Novi Paramita Dewi ${ }^{3}$, Ambar Teguh Sulistiyani ${ }^{4}$, \\ Lutfi Untung Angga Laksana ${ }^{5}$ \\ ${ }^{1}$ Corresponding Author, Department of Public Policy and Management, Faculty of Social and Political Sciences, \\ Universitas Gadjah Mada (email: i-made-krisnajaya@ugm.ac.id) \\ 2, 3, 4, 5 Department of Public Policy and Management, Faculty of Social and Political Sciences, \\ Universitas Gadjah Mada
}

\begin{abstract}
This study examines the political process of bureaucratic reform in Wonosobo regional government from 2011-2015. The article uses political and bureaucratic frameworks to describe the interplay of bureaucrats and politicians in the phases of bureaucratic reform. Data collection for this study employed document review and in-depth interviews with key informants. Results of the study show that the political process of bureaucratic reform mainly involved dialectical interactions between actors in the Wonosobo Regional Government and the Regional House of Representatives. The interplay of actors can then be explained through the actors' configuration, issues that are confronted by the actors, conflicts of interest between actors, and influence tactics used by actors in managing issues and struggling for their interests. The experience of the Wonosobo regional government shows that bureaucratic reform does not only concern technical and administrative capacities in carrying out institutional arrangement, but it also involves political aspects namely visionary leadership, strong political will to conduct reform, and effective use of influential tactics to gain political supports for the reform.
\end{abstract}

\section{Keywords:}

bureaucratic reform; political process; bureaucrat; politician; influence tactics

\section{Introduction}

Bureaucratic reform has been an essential part in the efforts to enhance the management of central and regional governments in Indonesia during the Reformation era. Bureaucratic reform has materialized into a national scale movement, wherein governments at the central, provincial, and regional level have been carrying out changes in various aspects of their bureaucracy in order to improve organization's internal management, the performance of the apparatus, and the quality of public services (Gaus, Sultan, \& Basri, 2017; Wihantoro et al., 2015; Dwiyanto, 2013; Kim, 2010). To the heads of governments, bureaucratic reform has become a compulsory program integrated in their development plans.
Amidst the intensity of bureaucratic reform movements in the regions, the reform carried out by Wonosobo Regional Government from 2011 to 2015 is an interesting phenomenon that captured the public's attention. This 'Wonosobo-style bureaucratic reform' is viewed as an extraordinary reform that brought about a controversy since it involved extreme downsizing and did not fully follow prevailing regulation, namely Government Regulation No. 41/2007 on Regional Government Organization. The anti-mainstream approach employed by the Wonosobo Regional Government was contradictory to the fact that bureaucratic reform policy in Indonesia at the time was rulebound and conservative in nature, wherein its 
execution must follow the particular concepts, procedures, and arrangements stipulated in the existing laws and regulations. Even more, the national policy on bureaucratic reform was also entrapped in the "bureaucratization of bureaucratic reform" and had more or less experienced uniformity (Purwanto et al., 2015, p. 1).

One of the contentious downsizing measures carried out at the time was the restructuring of several administrative matters that were previously organized within a Dinas (Department) into that of a Kantor (Office). The change from Department to Office had triggered a debate since the scale of an Office's organizational size is smaller than that of a Department. The downsizing actually had a huge impact on the quantity of organization units in the Wonosobo Regional Government. The most significant change which drew the public's attention was the dramatic 50\% reduction of Department organizations from 14 to 7. The Chairman of Special Committee (Panitia Khusus or Pansus) on Regional Regulation Draft on Regional Government Organizations claimed that these seemingly striking changes were expected to shape a new bureaucratic posture that is more functional and effective (Jumlah Dinas dari 14 Menjadi 7, 2014).

The experience of Wonosobo Regional Government shows that bureaucratic reform does not only cover technical-managerial aspects on institutional arrangement of regional government organizations, but it involves political facets as well. The combination of the two is reflected in the Regional Regulation No. 3/2014 on the Regional Government Organization of Wonosobo Regency (Peraturan Daerah No. 3/2014), which is a legislation produced out of Wonosobo Regency's bureaucratic downsizing. On one hand, the contents of the Regional Regulation No. 3/2014 were derived from results of academic study on Job and Work Load Analyses which involve the use of various competencies in the field of public administration, organizational development, and personnel management. On the other hand, Regional Regulation No.3/2014 is the output of a political process involving dynamic political activities between the bureaucrats of Wonosobo Regional Government and the politicians of Wonosobo Regional House of Representatives (Dewan Perwakilan Rakyat Daerah or DPRD).

It is important to note that the dynamics of the bureaucratic reform may be construed in the context of governance, wherein an understanding about the process leading to a particular change is required in order to figure out that change. As emphasized in a related study, "... governance is a dynamic outcome of social and political actors and therefore if changes are demanded then it is those dynamics that should be addressed" (Pierre \& Peters, 2000, p. 22). In other words, one of the best ways to understand the nature of bureaucratic reform is by depicting the political process that had occurred. It is based on this particular notion that this study on the political process of bureaucratic reform in Wonosobo Regional Government from 2011-2015 is of importance.

Regarding the process of bureaucratic reform, empirical experiences of several countries reveal that bureaucratic reform is mainly influenced by the political interplay of bureaucrats and politicians (Ricks, 2018; Dasandi \& Esteve, 2017; Alexander, Lewis \& Considine, 2011) and that regional governments are generally conservative in carrying out downsizing policies due to financial, legal, and political challenges (Berenschot, 2018; Liou \& Feldheim, 2018). However, study on the political process of bureaucratic reform focusing on the utilization of influence tactics by pro-reform bureaucrats in carrying out extreme bureaucratic downsizing is scarce. Therefore, the purpose of this study is to depict the political process of bureaucratic reform which covers: (1) issues that are confronted by bureaucrats and politicians; and (2) influence 
tactics used by pro-reform bureaucrats in managing issues and struggling for their interests.

\section{Stakeholder Analysis of Bureaucratic Reform}

Bureaucratic reform is the embodiment of what is called administrative reform. One of the interesting facts in this context is that bureaucratic reform has a long future and history. When the history of bureaucratic reform is traced back, it can be found as a part of administrative reform that has been taking place in the western world since the early 1980s (Boyd, 2009). Thus, bureaucratic reform should be seen as a long series of processes for continuing change which is not solely based on technical and administrative rationales, as it also involves political considerations (Peters, 2001, p. 143). In relation to this aspect of continuity, Dwiyanto (2016, p. 369) even considers that the changes implemented in bureaucratic reform are crucial in order to "free the bureaucracy from stagnation".

Aside from being an integral part of administrative reform, bureaucratic reform should be set as one of the forms of public policy in the government sector. In this case, public policy is defined as a series of decisions that are made through the political process. Jenkins defines public policy as: "a set of interrelated decisions taken by a political actor or group of actors concerning the selection of goals and the means of achieving them within a specified situation where those decisions should, in principle, be within the power of those actors to achieve" (Howlet \& Ramesh, 1995 , p. 5). Based on this definition, one way for understanding bureaucratic reform is by describing the political process that involves the interfaces of the related actors. Stakeholder analysis is, thus, highly relevant and of utmost importance.

A structured and accurate stakeholder analysis is required to understand a political process. According to Brinkerhoff \& Crosby
(2002), stakeholder analysis is focused on: “... assessing the nature of a policy's constituents, their interests, their expectations, the strength and intensity of their interest in the issue, and the resources that they can bring to bear on the outcomes of a policy change" (p. 141). By employing stakeholder analysis, we can identify the actors involved in the political process, the interests and expectations of the actors, and the capacity of the actors in influencing decision-making.

In the context of public policy, stakeholder analysis is essential in both formulation and implementation stages (Brinkerhoff \& Crosby, 2002). In the policy formulation stage, stakeholder analysis is beneficial for mapping the contestation of interests among the actors and for understanding which individuals or groups would benefit or be disadvantaged by the policy output produced. Whereas in the policy implementation stage, stakeholder analysis can help in understanding the map of actors' support in the policy implementation plan and strategy. It should be noted that the pros and cons of the actors during the policy formulation stage do not necessarily mean that the actors will have similar pros and cons in the implementation stage.

Basically, policy actors consist of elected officials, appointed officials, interest groups, research institutions, and mass media (Howlett \& Ramesh, 1995, p. 52). Elected officials include officers of the executive branch and members of the legislative directly elected by the people. Executive branch officials in the context of regional government in Indonesia refer to regional heads as political officials, i.e. governors, regents (bupati), and mayors. Legislative members include provincial and regional/municipal House of Representatives members who were elected in the legislative elections. Included in the category of appointed officials are bureaucrats, who are associated with career officials bearing a civil servant status who are tasked to assist the regional head 
in executing their administrative duties. While executive officials and legislative members are tasked to make policies, the bureaucrats are responsible for the implementation of those policies. Bureaucrats, in the context of regional government in Indonesia, include structural officials and employees of regional government organizations.

\section{Political Process in Bureaucratic Reform}

The process of bureaucratic reform is inseparable from the politics-bureaucracy boundary involving power struggles among bureaucrats and politicians (Gulzar \& Pasquale, 2017; Enikolopov, 2014; Aberbach \& Rockman, 2006). The relationship between bureaucrats and politicians can be categorized into the bureaucratic politics framework, which include: (1) bureaucrats versus bureaucrats; (2) bureaucrats versus politicians; and (3) politicians versus politicians (Bowornwathana \& Poocharoen, 2010, p. 305). The political process that takes place during the bureaucratic reform may involve these three types of contestation.

Conflictual interaction in the context of bureaucrats versus bureaucrats, for instance, may happen due to differing perspectives and disagreement among bureaucrats regarding the urgency of reform or the most appropriate concept of bureaucratic institutional arrangements. The interaction of bureaucrats versus bureaucrats also happens when a part of the bureaucracy has in fact become a target of bureaucratic reform itself, thereby leading to resistances manifested in the form of efforts undertaken to thwart, delay, and even sabotage the process of bureaucratic reform (Kim \& Han, 2015). Such reality should have a serious implication, particularly, on proreform bureaucrats; in which they are required to possess the political skills necessary for conducting two things, namely overcoming resistance from within the bureaucracy and garnering support from the stakeholders of bureaucratic reform.
In the context of bureaucrats versus politicians, politicians can be considered to hold a highly substantial role in determining the concept, scope, content, and scale of changes in bureaucratic reform (Peters \& Pierre, 2001). Caiden (1991) appropriately summarized how the political interests of politicians often trump technical-managerial considerations in the process of bureaucratic reform: "politicians have always intervened in the management of public organizations, sometimes paying attention to the smallest details and they have used administrative reform for purely political purposes, unrelated to managerial considerations" (p. 30). It is in this kind of situation that bureaucrats need to have certain political skills.

One of the vital political skills required for the bureaucrats to have is the ability to negotiate with politicians and other relevant actors (Johansson, 2012). Furthermore, Kipnis et al. (as cited in Anderson \& Kyprianou, 1994, p. 60) identified seven influential tactics that can be employed, namely: (1) 'assertiveness': to utilize one's communicative ability to persuade and convince others; (2) 'bargaining': to conduct negotiations based on mutual benefit; (3) 'coalition': to engage in a commitment of understanding with others; (4) 'friendliness': to utilize collegial or personal approaches; (5) 'higher authority': to garner support from those possessing higher authority or position in the organization; (6) 'reason': to present arguments based on data; (7) 'sanctions': to use incentives and disincentives in a situational manner. Effectiveness in applying those influence tactics, more or less, affects the process and outcome of bureaucratic reform.

\section{Methods}

This is a qualitative study that utilized the single case study approach, which according to Stake (as cited in Tight, 2010, p. 331), included a series of scientific activities carried out regarding a particular case focusing on 
"experiential knowledge of the case" and the relations with its social and political settings. The single case study approach was used as the phenomenon of 'Wonosobostyle bureaucratic reform' exemplified the accomplishment of pro-reform bureaucrats in carrying out anti-mainstream and extreme bureaucratic downsizing that had never before been exercised in Indonesian experience.

Data collection for this study employed two major activities, namely: document review and in-depth interviews. Document review was conducted by examining and analyzing relevant documents such as: books, journal articles, research reports, Job Analysis documents, Work Load Analysis documents, laws and regulations, and internet sources. In-depth interviews were conducted with key figures considered to have information and authority as a relevant source person on bureaucratic reform in Wonosobo Regional Government. The key figures include bureaucrats of Wonosobo Regional Government and academicians of Universitas Gadjah Mada (UGM) who were directly involved in the bureaucratic reform process. The use of these multiple data resources paved the way for the writers to do data triangulation and produce a better understanding on the process of bureaucratic reform. Data analysis techniques used in this study - as suggested by Miles, Huberman \& Saldana (2014) - comprises data collection, data processing, data interpretation, data analysis, data verification, and drawing conclusions.

\section{Results}

The process of bureaucratic reform in Wonosobo Regional Government from 2011 to 2015 can be divided into four phases, namely: (1) the process that involved conducting Job and Work Load Analyses up to determining the Regional Legislation Program (Program Legislasi Daerah or Prolegda); (2) the process that involved creating the Regional Regulation Draft (Rancangan Peraturan Daerah or Ranperda) up to adopting the Regional Regulation (Peraturan Daerah or Perda); (3) the process that involved adopting and executing said Regional Regulation; and (4) post implementation of Regional Regulation up to the submission of judicial review against that Regional Regulation to the Supreme Court (see Figure 1).

The discussions relating to those four phases are focused on the political process taking place within the context of relations between bureaucrats and politicians in the Government of Wonosobo Regency. However, before discussing the four phases, a brief explanation on the identification of actors involved in the process of bureaucratic reform and the interests of those actors is presented.

\section{Analysis on Bureaucratic Reform Actors at Wonosobo Regency from 2011 to 2015}

The stakeholders of bureaucratic reform in Wonosobo Regional Government from 2011 to 2015 included the Regional Government, the Regional House of Representatives, higher education institutions, and the media. As

Figure 1.

Phases of Bureaucratic Reform in Wonosobo Regional Government from 2011 to 2015

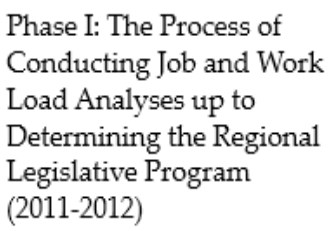

Phase I: The Process of Conducting Job and Work Determining the Regional (2011-2012)

\author{
Phase III: The Process \\ of Adopting up to \\ Executing the Regional \\ Regulation \\ (2014-2015)
}

Phase IV: Post implementation of Regional Regulation No. 3/2014 up to the Trial in the Supreme Court (2015)

Source: empirical research data, 2018. 
presented in Table 1, the actors included in the Regional Government were: Regent, Regional Secretary, Organizational Affairs Division, Legal Affairs Division, Secretariat of Regional House of Representatives, Regional Personnel Agency, and structural officials. Meanwhile, the actors from Regional House of Representatives were the members of Commission A and the Special Committee on Regional Regulation Draft on Regional Government Organizations. Whereas the higher education institution involved in this matter was Universitas Gadjah Mada (UGM).

A description of the interests of actors as presented in Table 1 reflects the pros and cons regarding the agenda of bureaucratic downsizing initiated by the Regent of Wonosobo and implemented by the Organizational Affairs Division. The actors in support of the downsizing included the Regent, the head of Organizational Affairs Division, the head of Legal Affairs Division, the secretary of Regional House of Representatives, some members in Commission A, and some members of the Special Committee. Meanwhile, the actors who were against the downsizing included, among others, the head of Regional Personnel Agency, structural officials and representatives of Regional Government Organizations targeted for downsizing, a number of politicians

Table 1.

Identification of Actors and Interests in Wonosobo Bureaucratic Reform 2011-2015

\begin{tabular}{|c|c|c|}
\hline No. & Name of Actors & Interests \\
\hline \multirow[t]{8}{*}{1} & Regional Government & \\
\hline & Regent & $\begin{array}{l}\text { Wanted to leave an impressive legacy in his final term by carrying out } \\
\text { bureaucratic downsizing }\end{array}$ \\
\hline & Regional Secretary & Did not want any negative impacts caused by the bureaucratic downsizing \\
\hline & $\begin{array}{l}\text { Head of Organizational } \\
\text { Affairs Division }\end{array}$ & $\begin{array}{l}\text { Interested in planning, executing, and addressing some of the impacts brought } \\
\text { about by the bureaucratic downsizing }\end{array}$ \\
\hline & $\begin{array}{l}\text { Head of Legal Affairs } \\
\text { Division }\end{array}$ & $\begin{array}{l}\text { Facilitated in planning and executing bureaucratic downsizing as well as } \\
\text { drafting the Regional Regulation }\end{array}$ \\
\hline & $\begin{array}{l}\text { Secretary of Regional House } \\
\text { of Representatives }\end{array}$ & $\begin{array}{l}\text { Facilitated the executive and legislative branches in drafting the Regional } \\
\text { Regulation }\end{array}$ \\
\hline & $\begin{array}{l}\text { Head of Regional Personnel } \\
\text { Agency }\end{array}$ & $\begin{array}{l}\text { Did not fully support the bureaucratic downsizing to evade from being merged } \\
\text { with Organizational Affairs Division }\end{array}$ \\
\hline & Structural Officials & Did not support the bureaucratic downsizing to avoid being demoted \\
\hline \multirow[t]{3}{*}{2} & $\begin{array}{l}\text { Regional House of } \\
\text { Representatives }\end{array}$ & \\
\hline & $\begin{array}{l}\text { Members of } \\
\text { Commission A }\end{array}$ & $\begin{array}{l}\text { The partners of Regional Government Organizations that address government } \\
\text { and legal affairs; some members did not want any negative impacts caused by } \\
\text { the bureaucratic downsizing }\end{array}$ \\
\hline & $\begin{array}{l}\text { Members of Special } \\
\text { Committee }\end{array}$ & Some Special Committee members did not support the bureaucratic downsizing \\
\hline 3 & $\begin{array}{l}\text { University Experts from } \\
\text { Universitas Gadjah Mada } \\
\text { (UGM) }\end{array}$ & $\begin{array}{l}\text { Provided assistance to the Organizational Affairs Division in conducting } \\
\text { Job and Work Load Analyses, and drafting the academic paper for Regional } \\
\text { Government restructuring }\end{array}$ \\
\hline 4 & $\begin{array}{l}\text { Journalist from } \\
\text { Jawa Pos/Radar Kedu }\end{array}$ & Conducted news coverage of the phases in the bureaucratic reform process \\
\hline
\end{tabular}

Source: Empirical research data, 2018. 
assembled in Commission A, and some members of the Special Committee.

The stance and actions chosen by the actors involved in the process of downsizing the bureaucracy in Wonosobo Regency as presented in Table 1 can be viewed from legalinstitutional as well as individual viewpoints. The structural officials in Regional Government Organizations targeted for downsizing, for example, emphasized the use of legal rationale and institutional analysis as the basis of their reason for not supporting the bureaucratic downsizing. The arguments they established were: (1) the agendas for bureaucratic downsizing are not in line with or are in opposition to the principles of regional government institutional arrangements regulated in Government Regulation No. 41/2007; and (2) the bureaucratic downsizing brought about instability within the Wonosobo Regional Government and it subsequently had an effect on the organization's declining performance, particularly in organizations that were downsized.

Regardless of the two "official" arguments that were presented, the rejection of bureaucratic downsizing by structural officials was also caused by more "personal" reasons: (1) demotion is understood as a reduction of one's power and authority over organizational resources; (2) demotion is considered to cause a drop in one's social status and pride; and (3) demotion leads to a lower amount of structural allowances and other income sources attached to the position held. Hence, both legal- institutional and individual viewpoints can be used to explain the actions chosen by the actors involved in the process of downsizing the bureaucracy in Wonosobo Regency.

\section{Phase I: The Process of Conducting Job and Work Load Analyses up to Determining the Regional Legislative Program (2011-2012)}

The process of bureaucratic downsizing in the Wonosobo Regional Government began by conducting Job and Work Load Analyses in 2011 (see Figure 2). The Work Load Analysis report indicated that a number of Regional Government Organizations in Wonosobo Regency had in fact been underloaded and the structure of Wonosobo Regional Government was considered to be overly bloated and dysfunctional (Sulistiyani, Susiawati \& Purwanti, 2014). This had subsequently prompted the Regent and the Organizational Affairs Division to initiate a policy of downsizing the bureaucracy with the purpose of restructuring institutional, personnel, and managerial affairs in Regional Government Organizations that were underloaded.

In 2012, the Organizational Affairs Division once again collaborated with UGM to conduct a review for composing an Academic Paper (Naskah Akademik) on the Regional Regulation Draft concerning Regional Government Organizations of the Wonosobo Regional Government. The Organizational Affairs Division created the initial structure of Wonosobo Regency's Regional Government Organizations and then had a consultation

\section{Figure 2.}

\section{The Process of Conducting Job and Work Load Analyses up to Determining Regional Legislative Program (2011-2012)}

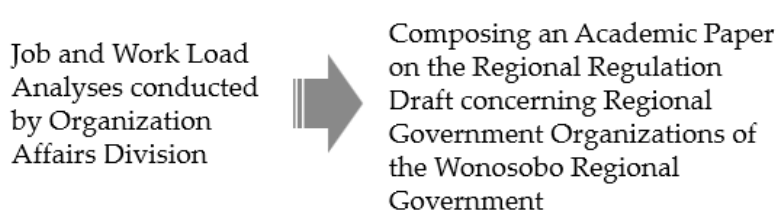

Source: Empirical research data, 2018.

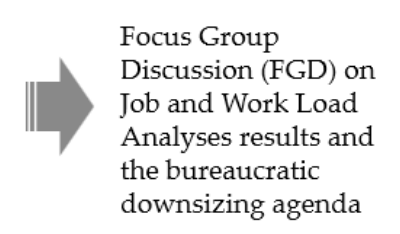
Proposal of Regional Regulation Draft on Regional Government Organizations of the Wonosobo Regional Government


with the team of experts from UGM. As a follow-up to the Job and Work Load Analyses that had been formerly carried out, the goal of composing this Academic Paper is that of downsizing the bureaucracy.

A rather interesting episode took place when the Organizational Affairs Division presented the results of the Job and Work Load Analyses during the Focus Group Discussion (FGD) attended by officials of Regional Government Organizations. The results of the Job and Work Load Analyses were considered shocking and they led to quite a heated debate. Department of Public Works (Dinas Pekerjaan Umum), for instance, highly opposed the work load analysis result indicating that their work load is actually not as much as they thought it was. According to the analysis result, the work load of Department of Public Works had been substantial because they had taken the amount of their sweepers into account in the calculation; if the sweepers had not been taken into account, the work load of Department of Public Works would then become insubstantial. This, consequently, had serious implications in reexamining the conformity between the size of Department of Public Works' organization and the work load it was tasked with at the time.

The plan to downsize the bureaucracy was immediately faced with pros and cons, bringing about resistance from within the Wonosobo Regional Government's own bureaucrats. The form of resistance carried out by the employees and structural officials at the time included passive and active rejections, which were manifested, among others, by obstructing and delaying the downsizing process, both explicitly and implicitly (Pratiwi, 2013). The resistance that developed at the time was focused on two main issues, namely the loss of a number of structural positions as a result of downsizing and the ambiguity concerning the criteria used to determine which structural officials would be demoted.

During the proposal of the Regional Regulation Draft, the Organizational Affairs Division was provided assistance by the Secretary of the Regional House of Representatives so that it could be included in the 2013 Regional Legislation Program. The Regional Legislation Program itself is defined in Law No. 12/2011 Article 1 Verse 10 as an instrument for the planning of Provincial Regulations or Regional/ Municipal Regulations that are arranged in a premeditated, integrated, and systematic manner. The Secretary of the Regional House of Representatives suggested that the Regional Regulation Draft proposal be submitted along with the other Draft in order to increase its chance of approval. This suggestion was carried out and both of the Regional Regulation Drafts proposed succeeded in being included in the 2013 Regional Legislation Program.

\section{Phase II: The Process of Drafting up to Adopting Regional Regulation (2012-2014)}

The creation of the Regional Regulation Draft regarding the regional Government Organizations officially began when the Regional House of Representatives formed a Special Committee to handle the legislation process (see Figure 3). The Special Committee

Figure 3.

The Process of Drafting up to Adopting Regional Regulation (2012-2014)

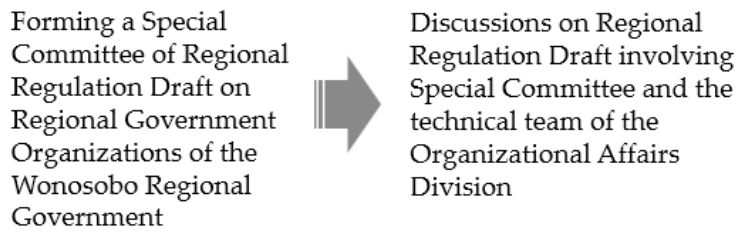

Discussions on Regional Regulation Draft involving Special Committee and the technical team of the Organizational Affairs Division

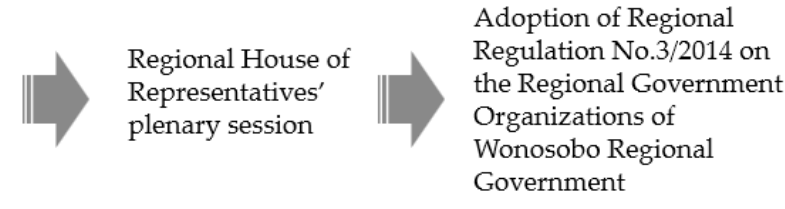

Source: empirical research data, 2018. 
was obviously split into two groups, one was for the downsizing while the other was against it. The pros and cons had subsequently manifested in dynamic political relations among the Special Committee members.

The discussion on the Regional Regulation Draft held between the Special Committee and the Technical Team of the Organizational Affairs Division was resplendent with heated debates among Committee members, particularly concerning the list of Regional Government Organizations that were going to be downsized. One of the influential factors in the pros and cons of Special Committee members was the phenomenon of plot politics, which led to several Special Committee members' proclivity towards Regional Government Organizations that handled certain governmental affairs. In the case of a certain Department that was associated with the interest of a political party, the Special Committee member coming from that party attempted to present arguments in defense of said Department so it would not be downsized. Following a rather intensive debate, the Technical Team of the Organizational Affairs Division finally convinced the Special Committee of the importance of downsizing the bureaucracy. One of the keys to the Team's success in winning the support of the Special Committee in relation to the plan for bureaucratic downsizing was their persuasive skills in using substantive arguments based on existing data.

In one of the Special Committee's internal meetings, the chairperson of the Regional House of Representatives specifically voiced the aspiration that a particular Department does not need to undergo downsizing. The debate openly recurred and any efforts of reaching a consensus had turned into a deadlock. The Special Committee then held a voting session to decide whether the Department being disputed needed to be downsized or not. At the time, the options offered to the voting participants were the "old concept" or the "Regional Regulation concept". The old concept was associated with the status quo, while the Regional Regulation concept referred to the bureaucratic downsizing proposed by the Organizational Affairs Division. The result of the voting showed that the majority of Special Committee members had elected to support the Regional Regulation concept. Based on the voting result, the Special Committee officially declared its support for the downsizing of the bureaucracy, hence rendering the discussion on the Regional Regulation Draft regarding the Regional Government Organization to continue running.

During the Regional House of Representatives' plenary session, an unusual incident happened; the matter of a Department targeted for downsizing was once again brought up and debated by a number of Regional House of Representatives members who still opposed the Regional Regulation concept. The fact that a debate about the fate of some Departments was reopened indicated unfinished and escalating arguments among the politicians. After going through a heated debate, the chair of the plenary session had ultimately tapped the hammer deciding that the Regional Regulation Draft on Regional Government Organizations was adopted as a Regional Regulation. The regulation that was formally legalized in the plenary session was accepted as Regional Regulation No.3/2014 on the Regional Government Organizations of Wonosobo Regional Government. The Regional Regulation was subsequently stipulated on January 30, 2014 and promulgated on April 10, 2014.

It should be noted that a number of structural officials who rejected bureaucratic downsizing had lobbied the Organizational Affairs Bureau of the Central Java Provincial Government in order to put a stop to the drafting of Regional Regulation. As provisioned in the legislation, every regulation draft proposed by a regional/municipal government must 
go through a substantive discussion stage and it must be given a registration number by the Central Java Provincial Government. However, the key officials of Central Java Provincial Government had supported the plan for downsizing, and they even countered the arguments of structural officials who opposed the regulation.

\section{Phase III: The Process of Adopting up to} Executing the Regional Regulation (2014-2015)

Although Regional Regulation No.3/2014 was declared effective as of July 1, 2014, it was not implemented for up to nearly a year after. Political dynamics regarding this issue remained active between the period of the adoption and the actual execution of the regulation. This period between adoption and execution was even considered as a year full of anxiety. This kind of impression was particularly suffered by employees and structural officials impacted by the downsizing. During this period, all Wonosobo Regional Government stakeholders had been waiting for the execution of the Regional Regulation with uncertainty. However, they were fully aware that the implementation of the Regional Regulation's mandate was only a matter of time; sooner or later the bureaucratic downsizing would have eventually happened.

Regional Regulation No.3/2014 was finally put into effect on April 17, 2015, which was marked with an inaugural ceremony of structural officials based on Regent of Wonosobo Decree No.821.2/055/BKD/2015 On Appointment, Mutation, and Termination of Structural Officials of Wonosobo Regional Government. The inauguration of structural officials indicated the success of the reformist group-represented primarily by the Organizational Affairs Division -in downsizing the bureaucracy within Wonosobo's Regional Government.

In relation to the implementation of Regional Regulation No. 3/2014, which was executed on April 17, 2015, the term of the Wonosobo Regent was about to end in October 2015. According to Law No. 1/2015 On Election of Head of Province and Regency/Municipal Article 71 Verse (2), the Regent is prohibited from changing government officials within six months prior to the end of the term. This implies that the Regent could not transfer any structural officials starting from the month of May until the month of October 2015. This means that the Regent would no longer be in charge as the regional head when excessive impacts from the implementation of Regional Regulation No.3/2014 emerged. The most significant implication in this case is that the Organizational Affairs Division had risen as the single institution from the Regional Government that had to address the negative impacts brought about by the bureaucratic downsizing.

Phase IV: Post implementation of Regional Regulation No. 3/2014 up to the Trial in the Supreme Court (2015)

Once Regional Regulation No. 3/2014 was implemented, it did not mean that the political dynamics had also come to an end. A number of former structural officials continued to react by submitting a judicial review on the Regional

Figure 4.

The Process of Adopting up to Executing the Regional Regulation (2014-2015)

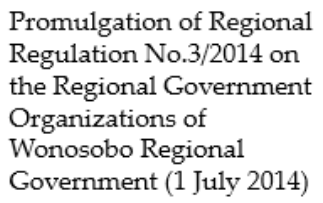

Promulgation of Regiona the Regional Government

Organizations of

Government (1 July 2014)

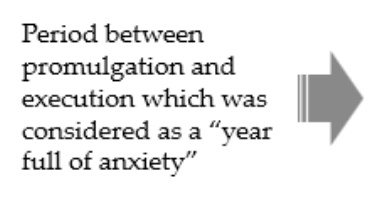

Execution of Regional Regulation No.3/2014 on the

Regional Government Organizations of Wonosobo Regional Government (17 April 2015)
Inauguration of structural officials based on Regent of Wonosobo Decree No.821.2/055/BKD/2015

Source: Empirical research data, 2018. 
Figure 5.

\section{Post implementation of Regional Regulation No. 3/2014 up to the Trial in the Supreme Court (2015)}

\begin{abstract}
Submission of a judicial review on the Regional Regulation No.3/2014 to the Supreme Court by demoted structural officials
\end{abstract}

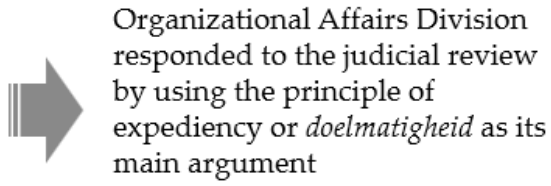

Rejection of judicial review by the Supreme Court, rendering the bureaucratic downsizing in Wonosobo Regional Government to continue as stipulated in the Regional Regulation No.3/2014

Source: Empirical research data, 2018.

Regulation No. 3/2014 to the Supreme Court (Tujuh PNS gugat perda OPD, 2015). The legal standing that the applicants based their action on was Article 9 verse (2) of Law No. 12/2011 which states: in the case that a legislation subordinate to the 1945 Constitution of the Republic of Indonesian is in conflict with said Constitution, the inquiry shall be conducted by the Supreme Court.

Actually, the judicial review filed against Regional Regulation No.3/2014 was not a surprise keeping in mind the resistance that occurred during the Regional Regulation's drafting process. The Wonosobo Regent responded to the lawsuit positively since he fully understood that every policy would undoubtedly have both positive and negative consequences. The Regent requested all officials of the Wonosobo Regional Government not to be influenced by the lawsuit and to continue "working in accordance with their appointment Decree and the main duties and functions they are responsible for" (Government of Wonosobo Regency, 2015).

Based on the input from UGM's team of experts, the Organizational Affairs Division decided to use the principle of expediency (doelmatigheid) as its main argument in responding to the judicial review filed against Regional regulation No. 3/2014. Several databased substantive arguments employed were: (1) downsizing the regional government organization structure is a manifestation of the rightsizing philosophy which is in line with Wonosobo Regional Government's necessity; (2) the reduction of structural positions is aimed at reducing bureaucratic hierarchy and enhancing efficiency in the organizational process; and (3) the utilization of middle line and functional positions through the formation of Office has increased the efficiency and performance of Regional Government Organizations in general. Ultimately, the judicial review was rejected by the Supreme Court, hence rendering the bureaucratic downsizing in Wonosobo Regional Government to continue as stipulated in the Regional Regulation No. 3/2014.

\section{Discussion}

The Wonosobo regional government experience from 2011-2015 substantiates the significance of visionary leadership, strong political will, and sufficient political skills in the accomplishment of bureaucratic reform. The involvement of these political aspects are of greater importance in the context of executing anti-mainstream and extraordinary bureaucratic downsizing, which has been found as an unpopular strategy in carrying out bureaucratic reform. Crawford (1996), for instance, asserts that the experience of bureaucratic reform in Australia proves that: "... both government leaders and senior public servants often approach the call for a new wave of reforms with little enthusiasm and much cynicism, asking instead for time to consolidate after the last change..." (p. 7). Other studies inform that senior bureaucrats, particularly those holding 
a conservative stance on ideas of reform, generally prefer the status-quo strategy and specifically support for bureaucracy upsizing rather than implementing a downsizing one (Santhitiwanich \& Bowornwathana, 2014; Gains \& John, 2010). It is based on this particular context that the study on the political process of bureaucratic reform in Wonosobo Regional Government from 2011-2015 will contribute to the existing literature.

The political process of bureaucratic reform in Wonosobo Regional Government primarily manifested in the form of dialectical interactions between bureaucrats and politicians. At this point, Wonosobo Regional Government experience confirms the bureaucratic and political frameworks suggested by Bowornwathana \& Poocharoen (2010), which comprise the relations between bureaucrats and bureaucrats, bureaucrats and politicians, and politicians and politicians. The dialectical interactions can then be explained through four factors, namely the configuration of the actors involved, issues that are confronted by actors, conflicts of interest between actors, and tactics used by actors in managing issues and struggling for their interests (see Table 2 ). The dynamics of the bureaucratic reform process, therefore, is determined by the interplay of actors in handling those factors.

As seen in Table 2, the most crucial issue addressed by the Organizational Affairs Division and politicians of the House is the decision on the list of regional government organizations targeted for downsizing. This issue had been the focal point in all phases of bureaucratic downsizing on which the conflict of interests between actors are based. The findings of this study show that the Organizational Affairs Division, which represented the pro-reform groups in Wonosobo Regional Government, had successfully handled the issues as well as taken care of their interests. The adoption and execution of Regional Regulation No. 3/2014 confirms the success of pro-reform bureaucrats in winning the dynamic interplay between them and the other actors involved in the bureaucratic reform.

Table 2.

Dialectical Interactions between Bureaucrats and Politicians in Bureaucratic Reform in Wonosobo Regional Government from 2011 to 2015

\begin{tabular}{|c|c|c|c|}
\hline & Bureaucrat and Bureaucrat & Bureaucrat and Politician & Politician and Politician \\
\hline Actors & $\begin{array}{l}\text { Regional Secretary, head of } \\
\text { Organizational Affairs Division, } \\
\text { head of Regional Personnel Agency, } \\
\text { demoted structural officers }\end{array}$ & $\begin{array}{l}\text { Regent, head of Organizational } \\
\text { Affairs Division, chairperson } \\
\text { of the House, members of } \\
\text { Commission A, members of } \\
\text { Special Committee }\end{array}$ & $\begin{array}{l}\text { Members of Commission } \\
\text { A, members of Special } \\
\text { Committee }\end{array}$ \\
\hline Issues & $\begin{array}{l}\text { Reduction of the numbers of } \\
\text { regional government organizations, } \\
\text { restructuring of underloaded } \\
\text { departments, reduction of structural } \\
\text { positions, demotion of structural } \\
\text { position echelons }\end{array}$ & $\begin{array}{l}\text { Reduction of the numbers } \\
\text { of regional government } \\
\text { organizations, decision on the } \\
\text { list of regional government } \\
\text { organizations targeted for } \\
\text { downsizing }\end{array}$ & $\begin{array}{l}\text { Decision on determining } \\
\text { the Regional Legislative } \\
\text { Program, decision on } \\
\text { adopting Regional } \\
\text { Regulation No.3/2014 }\end{array}$ \\
\hline Interests & $\begin{array}{l}\text { Efficiency and performance of } \\
\text { internal management in regional } \\
\text { government organizations, } \\
\text { organizational stability }\end{array}$ & $\begin{array}{l}\text { Legacy, efficiency and } \\
\text { performance of regional } \\
\text { government organizations, } \\
\text { organizational stability, political } \\
\text { stability }\end{array}$ & $\begin{array}{l}\text { Access to political and non- } \\
\text { political resources, political } \\
\text { stability, electability }\end{array}$ \\
\hline Tactics & $\begin{array}{l}\text { Assertiveness, friendliness, higher } \\
\text { authority, reason, coalition }\end{array}$ & $\begin{array}{l}\text { Assertiveness, friendliness, } \\
\text { higher authority, reason, } \\
\text { bargaining, coalition }\end{array}$ & Bargaining, coalition \\
\hline
\end{tabular}

Source: Empirical research data, 2018. 
It is important to note that the success of bureaucratic reform in Wonosobo Regency is predominantly determined by the ability of the Organizational Affairs Division in winning support from politicians in the Regional House of Representatives amidst the resistance by some internal bureaucrats and politicians. The ability mainly involved effective use of influential tactics in each phase of bureaucratic reform, which cover those suggested by Kipnis et al. (as cited in Anderson \& Kyprianou, 1994, p. 60) namely assertiveness, bargaining, coalition, friendliness, higher authority, and reason.

In practice, those influence tactics were exercised by: (1) using skills in persuasion, communication, and argumentation in formal forums to convince bureaucrats and politicians to support downsizing; (2) engaging in negotiations with politicians by emphasizing that by supporting the bureaucratic downsizing the politicians would gain credit from their constituents and increase their electability; (3) fostering commitment of understanding with politicians in Commission $\mathrm{A}$ and the Special Committee to carry out bureaucratic downsizing; (4) utilizing a personal approach through informal channels in order to gain support from politicians in Commission A and the Special Committee; (5) approaching immediate superiors, namely the Regent and Regional Secretary, so that they would exercise their authority and influence to safeguard and facilitate the downsizing process; and (6) using the Job and Work Load Analyses results as main arguments to support the policy for downsizing the bureaucracy and exposing substantive-pragmatic arguments in order to cope with resistance.

\section{Conclusion}

The political process in the course of bureaucratic reform in Wonosobo Regional Government from 2011 to 2015 mainly involved dialectical interactions between actors in the Wonosobo Regional Government and the Regional House of Representatives. The interplay of actors can then be explained through the actors' configuration, issues that are confronted by actors, conflicts of interest between actors, and influence tactics used by actors in managing issues and struggling for their interests. The experience of Wonosobo regional government shows that bureaucratic reform is not only concerned with technical and administrative capacities in carrying out institutional arrangement, but it also involves political aspects namely visionary leadership, strong political will to conduct reform, and effective use of influence tactics to gain political supports for the reform.

\section{Annotation}

This article is developed from results of a study entitled Bureaucratic Reform Politics: Lessons from Wonosobo Regency's Institutional Restructuring of Regional Government Organizations from 2011 to 2015. This study was funded by the Research Directorate of Universitas Gadjah Mada under the 2018 Young Lecturers Research Capacity Building scheme.

\section{References}

Aberbach, J. D., \& Rockman, B. A. (2006). The past and future of political-administrative relations: Research from bureaucrats and politicians to in the web of politics - and beyond. International Journal of Public Administration, 29(12), 977-995. doi: 10.1080/01900690600854589

Anderson, A. H. \& Kyprianou, A. (1994). Effective organizational behaviour: A skills and activity-based approach. Oxford: Blackwell Publishers.

Alexander, D., Lewis, J. M. \& Considine, M. (2011). How politicians and bureaucrats network: A comparison across governments. Public Administration, 89(4), 1274-1292. doi: 10.1111/j.14679299.2010.01890.x 
Berenschot, W. (2018). Incumbent bureaucrats: Why elections undermine civil service reform in Indonesia. Public Administration E Development, 38(4), 135-143. doi: 10.1002/ pad.1838

Bowornwathana, B., \& Poocharoen, O. (2010). Bureaucratic politics and administrative reform: Why politics matters. Public Organization Review, 10(4), 303-321. doi: 10.1007/s11115-010-0129-0

Boyd, N. M. (2009). Administrative reform in the States. Public Administration Quarterly, 33(2), 155-163.

Brinkerhoff, D. W., \& Crosby, B. L. (2002). Managing policy reform: Concepts and tools for decision-makers in developing and transitioning countries. Connecticut: Kumarian Press.

Caiden, G. E. (1991). Administrative reform comes of age. New York: deGruyter.

Crawford, P. J. (1996). The serious business of governing: Reform in government $\mathcal{E}$ transformation in the public sector. New South Wales: Southwood Press.

Dasandi, N., \& Esteve, M. (2017). The politicsbureaucracy interface in developing countries. Public Administration $\mathcal{E}$ Development, 37(4), 231-245. doi: 10.1002/ pad.1793

Dwiyanto, A. (2016). Memimpin perubahan di birokrasi pemerintah: Catatan kritis seorang akademisi. Yogyakarta: Gadjah Mada University Press.

Dwiyanto, A. (2013). Mengembalikan kepercayaan publik melalui reformasi birokrasi. Jakarta: Gramedia Pustaka Utama.

Enikolopov, R. (2014). Politicians, bureaucrats and targeted redistribution. Journal of Public Economics, 120(C), 74-83.

Gains, F. \& John, P. (2010). What do bureaucrats like doing? Bureaucratic preferences in response to institutional reform. Public Administration Review, 70(3), 455-463.

Gaus, N., Sultan, S., \& Basri, M. (2017). State bureaucracy in Indonesia and its reforms: An overview. International Journal of
Public Administration, 40(8), 658-669. doi: 10.1080/01900692.2016.1186179

Government of Wonosobo Regency. (2015, July 23). Hadapi judicial review perda OPD dengan bahagia, Bupati minta semua pejabat tetap bekerja. Retrieved from https://wonosobokab.go.id/website/ index.php/berita/seputar-wonosobo/ item/3772-hadapi-judicial-review-perdaopd-dengan-bahagia-bupati-mintasemua-pejabat-tetap-bekerja.

Government Regulation of the Republic of Indonesia No. 41/2007 on Regional Government Organization.

Gulzar, S. \& Pasquale, B. J. (2017). Politicians, bureaucrats, and development: Evidence from India. The American Political Science Review, 111(1), 162-183.

Howlett, M \& Ramesh, M. (1995). Studying public policy: Policy cycles and policy subsystems. Oxford: Oxford University Press.

Johansson, V. (2012). Negotiating bureaucrats. Public Administration, 90(4), 1032-1046. doi: 10.1111/j.1467-9299.2012.02025.x

Kim, S., \& Han, C. (2015). Administrative reform in South Korea: New public management and the bureaucracy. International Review of Administrative Sciences, 81(4), 694-712. doi: 10.1177/00200852314558034

Kim, P. S. (2010). Civil service system and civil service reform in ASEAN member countries and Korea. Seoul: Choon Whan Lim Daeyoung Moonhwasa Publishing Company.

Law of the Republic of Indonesia No. 1/2015 On Election of Head of Province and Regency/Municipal.

Liou, K. T \& Feldheim, M. A. (2018). Implementing downsizing reforms in county governments. Public Administration Quarterly, 42(1), 32-58.

Miles, M. B., Huberman, M. \& Saldana, J. (2014). Qualitative data analysis (3rd ed). London: Sage.

Peters, B. G. (2001). The future of governing (2nd ed). Kansas: University Press of Kansas. 
Peters, B. G \& Pierre, J. (2001). Politicians, bureaucrats and administrative reform. London: Routledge.

Pierre, J \& Peters, B. G. (2000). Governance, politics and the state. London: MacMillan Press.

Pratiwi, L. N. (2013). Resistensi dan akseptabilitas pegawai terhadap rencana restrukturisasi organisasi perangkat daerah di Kabupaten Wonosobo. Yogyakarta: Departemen Manajemen dan Kebijakan Publik, Fakultas Ilmu Sosial dan Ilmu Politik, Universitas Gadjah Mada.

Purwanto, E. A., Pramusinto, A., Kumorotomo, W., Widaningrum, A., Subarsono, A., \& Apriliyanti, I. D. (2015). Menggagas peta jalan reformasi birokrasi. Yogyakarta: Gadjah Mada University Press.

Tujuh PNS gugat perda OPD. (2015, June). Radar Kedu. Retrieved from https://www. radarkedu.com/2015/06/18/tujuh-pnsgugat-perda-opd.

Jumlah Dinas dari 14 Menjadi 7. (2014, January 4). Radar Semarang. Retrieved from http:// radarsemarang.com/2014/01/04/jumlahdinas-dari-14-menjadi-7/.

Regent of Wonosobo Decree No. 821.2/055/ BKD/2015 on Appointment, Mutation, and Termination of Structural Officials of Wonosobo Regional Government.

Regional Regulation of Wonosobo Regency No. 3/2014 on Regional Government Organizations of Wonosobo Regency.

Ricks, J. I. (2018). Agents, principals, or something in between? Bureaucrats and policy control in Thailand. Journal of East Asian Studies, 8(3), 321-344. doi: 10.1017/jea.2018.17

Santhitiwanich, A., \& Bowornwathana, B. (2014). Political strategy of senior bureaucrats in structural expansion in Thailand. International Journal of Humanities and Social Science, 4(5), 182-189.

Sulistiyani, A. T., Susiawati, M., \& Purwanti, N. D. (2014). Teori dan implementasi birokrasi organisasi: Agenda penataan organisasi perangkat daerah Kabupaten Wonosobo. Sleman: Independent Generation.

Tight, W. (2010). The curious case of case study: A viewpoint. International Journal of Social Research Methodology, 13(4), 329-339. doi: 10.1080/13645570903187181

Wihantoro, Y., Lowe, A., Cooper, S. \& Manochin, M. (2015). Bureaucratic reform in post-Asian crisis Indonesia: The directorate general of tax. Critical Perspectives on Accounting, 31, 44-63. doi: 10.1016/j.cpa.2015.04.002 